\title{
Smog episodes in the Lodz agglomeration in the years 2014-17
}

\author{
Grzegorz Wielgosiński ${ }^{1,}{ }^{*}$, Justyna Czerwińska ${ }^{1}$, Olga Namiecińska $^{1}$ and Robert Cichowicz ${ }^{2}$ \\ ${ }^{1}$ Lodz University of Technology, Faculty of Process and Environmental Engineering, \\ Wólczańska St. 175, 90-924 Lodz, Poland \\ ${ }^{2}$ Lodz University of Technology, Faculty of Architecture, Civil and Environmental Engineering, \\ Al. Politechniki St. 6, 90-924 Lodz, Poland
}

\begin{abstract}
In recent years, in the winter season we are alarmed about the poor air quality in Poland and significantly exceeded permissible concentrations of certain pollutants, especially PM10 and PM2.5, which are a result of so-called low emissions. The authors analyze smog episodes in the Lodz agglomeration by comparing the recorded values of selected pollutant concentrations at monitoring stations of the Regional Inspectorate for Environmental Protection in Lodz with the meteorological conditions prevailing at this time. The analysis covers data from the years 2014-2017.
\end{abstract}

\section{Introduction}

Currently, the most important or most hazardous pollutants emitted into the atmosphere are sulfur dioxide, nitrogen oxides, carbon monoxide and particulate matter, i.e. PM2.5 and PM10. Poland is one of the most polluted countries in the European Union in terms of the amount of these compounds in the atmospheric air [1-4]. At the same time, according to the latest report of the World Health Organization (WHO) [5,6], out of the top ten polluted cities seven are in Poland. These are Rybnik, Wodzisław Śląski, Opoczno, Sucha Beskidzka, Godów and Kraków, Skawina and Nowy Sącz. Unfortunately, apart from the above mentioned cities, also in other regions of Poland there are numerous places with exceeded permissible pollutant concentrations in the atmospheric air [7-10]. In summer it is usually tropospheric ozone, while in winter this are mainly particulate matter PM10 [27] and carcinogenic benzo(a)pyrene. Elevated levels of these substances are primarily caused by low emissions, mainly road transport and municipal sector (individual heating systems). Significant part of urban air pollution is also caused by the lack or building up of the preexisting 'urban ventilation corridors' [11]. Compact and high-rise buildings cause the accumulation of harmful substances in central areas of cities. In addition, the concentration of pollutants is also enhanced by climatic conditions such as low rainfall and windless weather. In this case smog is formed [12-16] - a phenomenon which was particularly burdensome last winter (2016/2017). At the same time, it should be borne in mind that the main sources of particulate matter include road transport, municipal combustion processes, agriculture, CHP and power plants, and numerous manufacturing processes in industry

${ }^{*}$ Corresponding author: grzegorz.wielgosinski@p.lodz.pl 
[17-21]. All of these elements make up the so-called 'low emission', i.e. emission of pollutants from the emitters of a height not exceeding $40 \mathrm{~m}$ [22-25].

The presence of particulate matter in the atmosphere is a phenomenon very bad for human health. Large amounts of suspended particulate matter can cause atherosclerosis and respiratory system diseases (children and the elderly are particularly vulnerable) [26-30].

Literature distinguishes two kinds of smog - one is a photochemical smog, also known as 'Los Angeles smog' because of its main area of occurrence. The time of its formation covers the period from June to September with light winds and high temperature (over $30^{\circ} \mathrm{C}$ ). Its main cause is the presence of nitrogen oxides and hydrocarbons from automotive exhaust occurring in the atmosphere. In the presence of solar radiation, these compounds react producing strong oxidants, mainly ozone. As a result of these reactions a brownish mist can be observed floating over the city, which greatly limits the view $[31,32]$.

Another type of smog is a sour smog, also called 'London smog'. In contrast to photochemical smog, it is formed at low air temperatures near $0^{\circ} \mathrm{C}$. Factors causing this phenomenon are the lack of air mass movement at high humidity and temperature inversion, as well as high concentration of sulfur, nitrogen and carbon oxides in the air [33].

In recent years it has been noticed that the smog formed in Poland in winter is neither photochemical nor acid smog. This smog, which can be called a 'Polish smog', consists mainly of PM10, PM2.5, PM1 and polycyclic aromatic hydrocarbons, including benzo(a)pyrene. The resulting smog is a consequence of the processes of burning solid fuels in low efficiency furnaces which are not equipped with exhaust gas treatment systems. As a consequence during winter this phenomenon is intensified, which is related to weather in our climate [34]. It is most often generated at temperatures below $0^{\circ} \mathrm{C}$ in windless anticyclone weather under the conditions of temperature inversion.

\section{Description of the problem}

The Lodz agglomeration (with a population of about 1.1 million people) is located in central Poland in the Lodz Region (18 $218.95 \mathrm{~km}^{2}$, population 2488417 and population density 136.6 inhabitants $/ \mathrm{km}^{2}$ ). Its central city is Lodz (with an area of $29,325 \mathrm{~km}^{2}$, population 693797 and population density 2366 inhabitants $/ \mathrm{km}^{2}$ ) [35]. In this area majority of the industry of the whole Lodz province is concentrated. The towns belonging to the Lodz Agglomeration are (Fig 1): Lodz, Pabianice, Zgierz, Aleksandrów Łódzki, Ozorków, Konstantynów Łódzki, Głowno, Koluszki, Brzeziny, Tuszyn, Stryków and Zgierz [36].

The analysis of changes in air pollution in the Lodz agglomeration was based on data from 2 measurement stations (Fig. 2) [37] performing automatic measurements, and located in Lodz: Station 1, i.e. Lodz-Widzew (launch date: 1 November 2003) and Station 2, i.e. Lodz-Gdańska 16 (launch date: 1 January, 2012).

The first station, i.e. Station 1 , is located in the eastern part of the city at $1 / 3$ Czernika str. It covers the area of Lodz-Widzew district. This is a container automatic measurement station located at $235 \mathrm{~m}$ a.s.l. to measure the following parameters: $\mathrm{SO}_{2}, \mathrm{NO}_{2}, \mathrm{CO}, \mathrm{PM} 2.5$, $\mathrm{PM} 10, \mathrm{NO}, \mathrm{NO}_{\mathrm{x}}$ and $\mathrm{O}_{3}$. In its neighborhood in the north, south and west, there is a scattered multi-family housing. In the east, the station neighbors a park and recreational areas. The main sources of emission in the vicinity of the station include a large municipal heat and power plant (EC-4) and car transport.

The second analyzed station, i.e. Station 2, is located in the central part of the city at 16 Gdańska Street. It covers the area of Lodz-Śródmieście district. It is also a container automatic measurement station located at $206 \mathrm{~m}$ a.s.l. and measures such parameters as $\mathrm{SO}_{2}, \mathrm{NO}_{2}, \mathrm{CO}$, benzene, PM2.5, PM10, $\mathrm{NO}, \mathrm{NO}_{\mathrm{x}}$ and $\mathrm{O}_{3}$. In its neighborhood in the north, south and east, there is a compact multi-family housing. In the west, the station neighbors commercial, service, school and office buildings. The main sources of emissions in the 
vicinity of the station are heating/fuel combustion systems in commercial premises, offices and apartments and car transport.

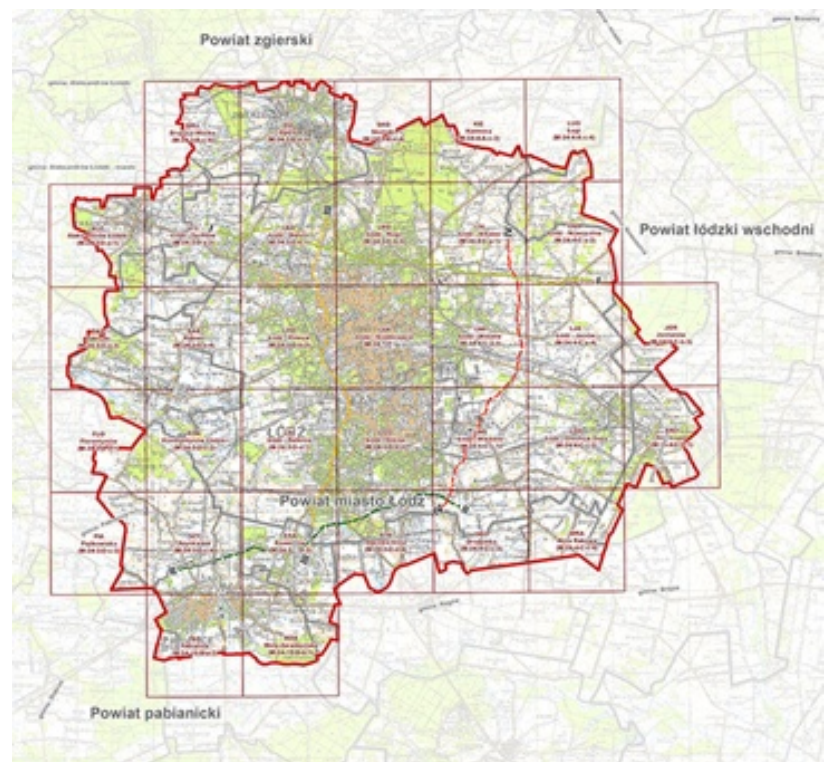

Fig. 1. Lodz agglomeration

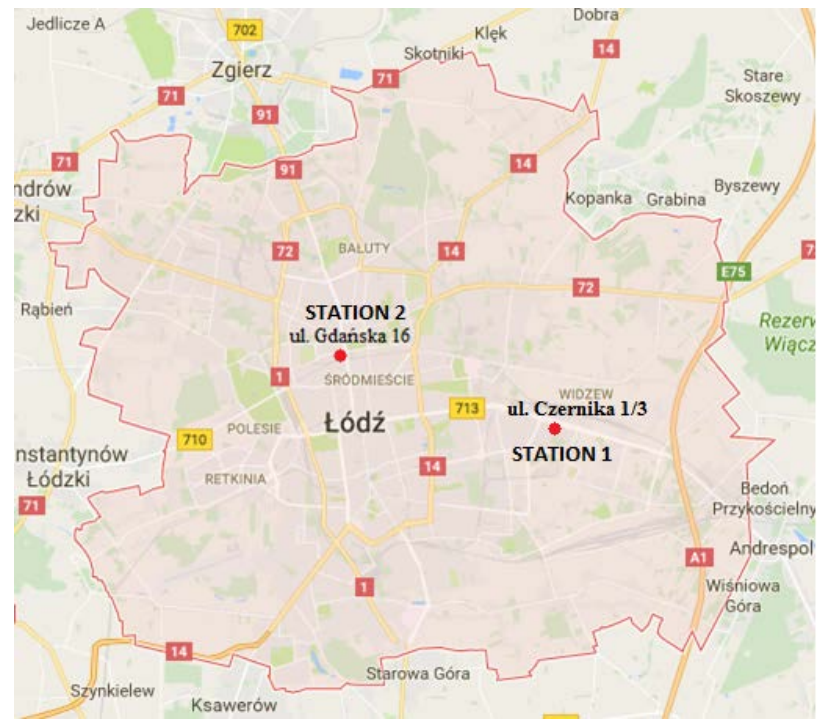

Fig. 2. Location of measurement stations in the city of Lodz

\section{Results}

Changes in the concentration of the two most important pollutants being the main constituents of the so-called 'Polish smog', i.e. suspended particulate matter PM10 and PM2.5, were analyzed at two measurement stations in the Lodz agglomeration in the years 
2014-2017. The effects of atmospheric conditions on changes in PM10 and PM2.5 concentrations during the recorded smog episodes were analyzed.

Figure 3 shows the concentration distribution of PM2.5 and PM10 depending on the atmospheric pressure for the period of smog which was registered on 5 to 7 January 2016. When analyzing the data, it can be seen that the highest PM10 concentration was recorded at atmospheric pressure of $973 \mathrm{hPa}$ and the lowest at $974 \mathrm{hPa}$. For PM2.5 no influence of atmospheric pressure was observed. In both cases the highest values were read on Station 2, i.e. in the city center.

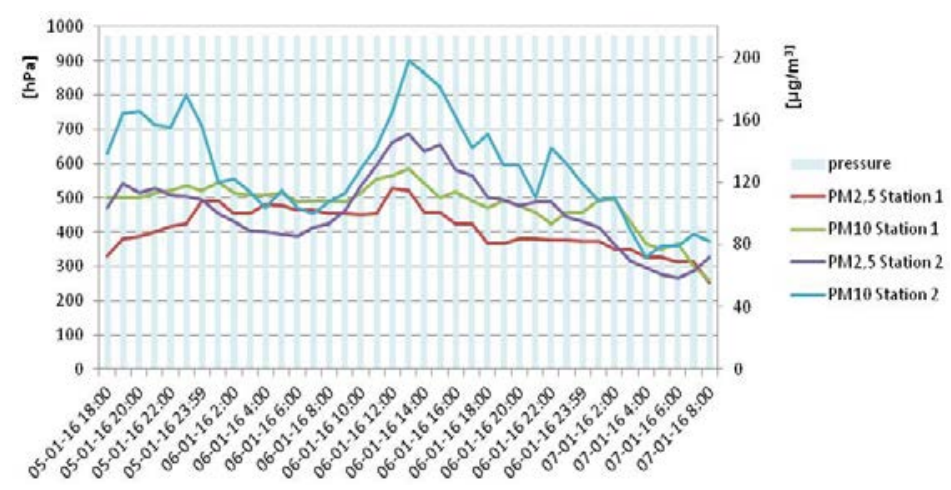

Fig. 3. Dependence of PM10 and PM2.5 concentrations on pressure

Figure 4 shows the distribution of PM2.5 and PM10 concentrations depending on the temperature for the period of smog which was recorded on 5 to 7 January 2016. From this characteristic it can be seen that smog appeared in the temperature range from $-10.4^{\circ} \mathrm{C}$ to $-5^{\circ} \mathrm{C}$. This is a novelty compared to the classic type of smog and it can be assumed that this is an obvious example of the so-called 'Polish smog' - particulate matter recorded at temperatures below zero.

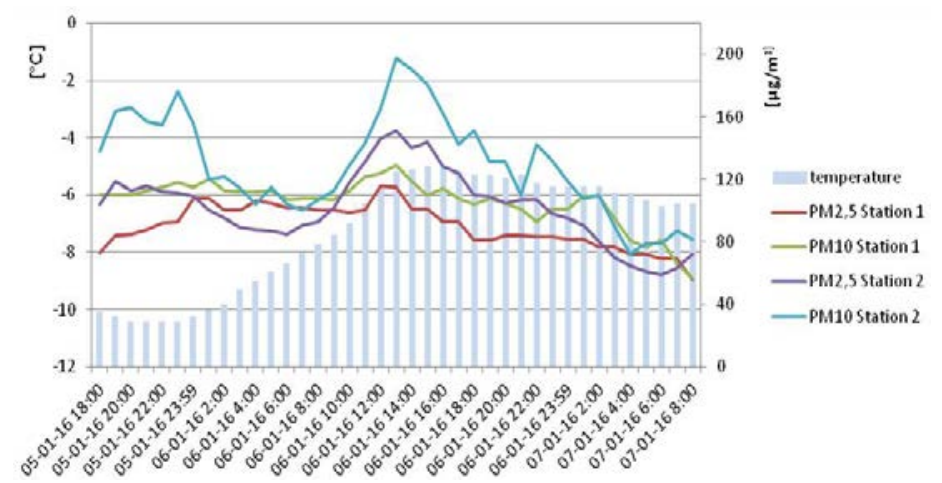

Fig. 4. Dependence of PM10 and PM2.5 concentrations on temperature

Figure 5 shows the distribution of PM2.5 and PM10 concentrations depending on wind speed for the period of smog which was measured on 5 to 7 January 2016. The figure shows that in the analyzed time the wind speed varied from 1.4 to $2.5 \mathrm{~m} / \mathrm{s}$. As expected, there is a positive effect of wind speed on the state of air pollution, i.e. the higher the wind speed, the more accurately the city is ventilated and the concentrations of pollutants are smaller. 


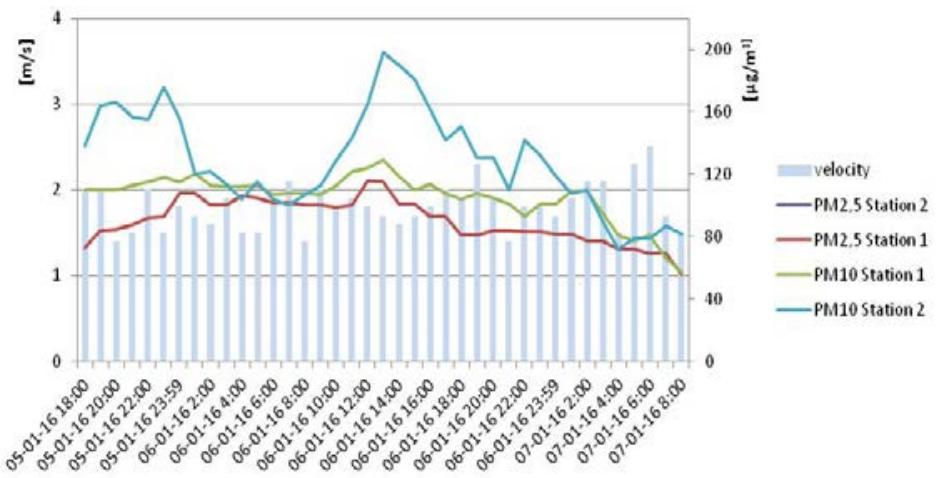

Fig. 5. Dependence of PM10 and PM2.5 concentrations on wind speed

Figure 6 shows the distribution of PM2.5 and PM10 concentrations depending on the absolute humidity for the period of smog which was measured on 5 to 7 January 2016. When analyzing the data, it can be seen that higher concentration values were measured on Station 2, i.e. in the city center. In addition, the maximum humidity varied between $80-90 \%$ and as expected, the higher humidity the more particle matter trapped in the air and the higher the particulate matter concentration.

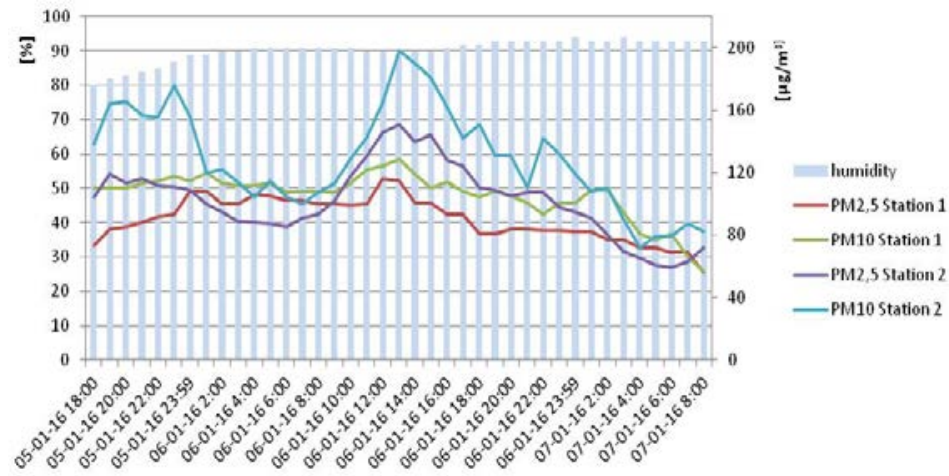

Fig. 6. Dependence of PM10 and PM2.5 concentration on absolute humidity

All drawings (Figure 3-6) show a clear (expected) correlation between PM10 and PM2.5 concentrations and the dependence of the recorded concentrations on stations 1 and 2 .

Summing up data on air pollution in the Lodz agglomeration, Table 1 presents information on the number of days during which smog episodes occurred, as recorded on the first or second station analyzed.

Table 1. Number of smog days in 2014-17 recorded on two analyzed stations.

\begin{tabular}{|c|c|c|}
\hline YEAR & STATION 1 & STATION 2 \\
\hline 2014 & 28 & 59 \\
\hline 2015 & 27 & 59 \\
\hline 2016 & 19 & 55 \\
\hline 2017 & 28 & 44 \\
\hline
\end{tabular}


Station 2, located in the city center, recorded significantly more smog days, with exceeded permissible levels of suspended particulate matter in the air than Station 1 located outside the strict city center, in the area of new housing estates. This confirms the thesis that the main source of air pollution in the Lodz agglomeration are low emissions from individual heating systems which dominate the city center. In the area of new housing estates heated by a central system (CHP plant) air quality is much better, even in periods that are particularly conducive to smog formation.

When analyzing the monitoring data, we attempted to find a correlation between meteorological parameters (pressure, temperature, wind speed and air humidity) and immission of pollutants - in this case PM10. This is illustrated in Figures 7 to 10. Data are presented for Station 1 in 2016.

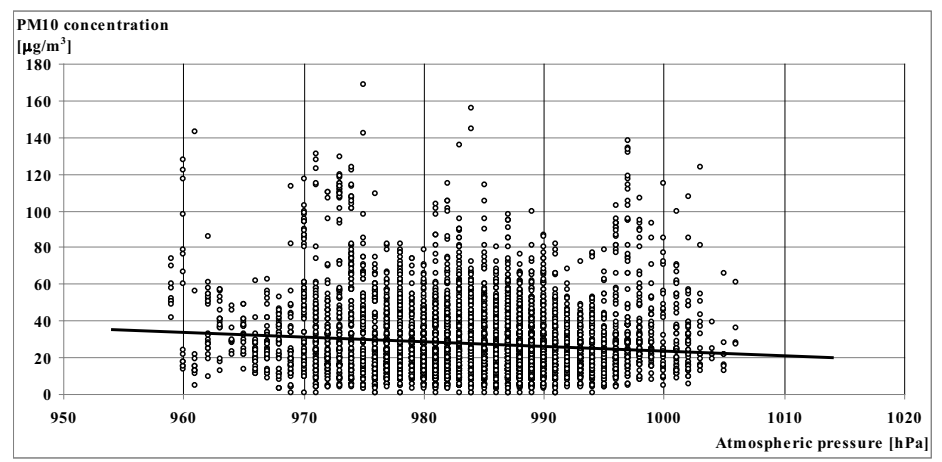

Fig. 7. Dependence of PM10 concentration on atmospheric pressure

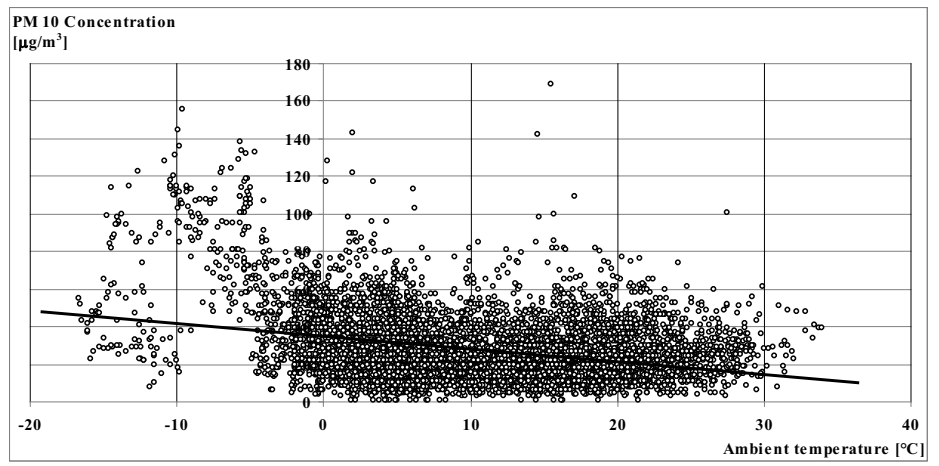

Fig. 8. Dependence of PM10 concentration on air temperature 


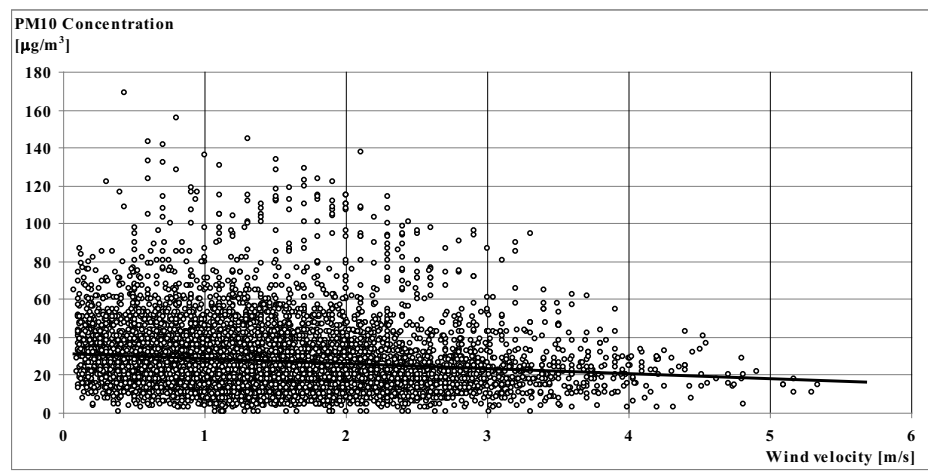

Fig. 9. Dependence of PM10 concentration on wind speed

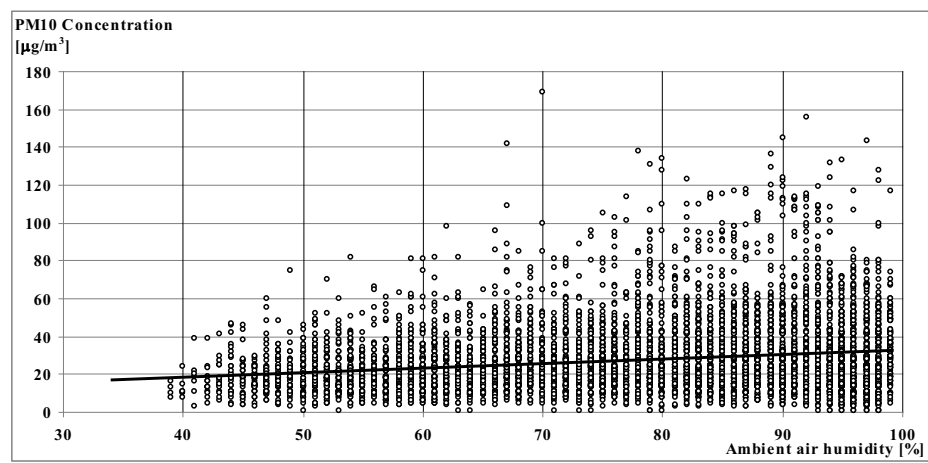

Fig. 10. Dependence of PM10 concentration on air humidity

As it is easy to see, there is a correlation between some meteorological factors and the concentration of PM10. The concentration of PM10 decreases with increasing atmospheric pressure (Fig. 7), temperature (Fig. 8) and wind speed (Fig. 9), while rises with air humidity increase (Fig. 10).

It is no use to make a detailed analysis of correlation and its relevance between PM10 concentration and air temperature, atmospheric pressure, wind speed and air humidity, for the calculated correlation coefficients are very small for this amount of monitoring data and the variability of the parameters. It is important, however, that such dependencies exist, and although the influence of wind speed is obvious, but the dependence on air temperature and atmospheric pressure clearly indicates the difference in recorded smog phenomena from the described in the literature so-called London type smog.

\section{Conclusions}

Numerous literature reports $[3,4]$ indicate that air quality in Poland is poor. Especially it is observed in the south of the country and in the cities with a residential center built in the early 20th century, heated by individual heating systems. Smog events in Poland appear each year in the winter season. Particularly PM10 and PM2.5 concentrations are exceedingly high, with relatively low concentrations of sulfur dioxide, nitrogen oxides and carbon monoxide. 
The paper analyzes smog episodes in the Lodz agglomeration in the years 2014-17. The analysis is based on results from two stations of automatic air quality monitoring located in Lodz. It was found that there the recorded concentrations of PM10 and PM2.5 depended on certain meteorological parameters. At both stations it was observed that PM10 and PM 2.5 concentrations decreased with the increase of air temperature, atmospheric pressure and wind speed, and rose with increasing air humidity. This confirms the thesis on the difference between smog recorded recently in Poland and typical cases described in the literature, i.e. acidic (London) smog and photochemical (Los Angeles type) smog. The 'Polish smog' is characterized by the presence of very high concentrations of particulate matter at high-pressure weather, negative temperatures and at light winds.

This type of weather usually occurs in Poland in winter, when strong Russian anticyclone stabilizes the clear, sunny weather with low winds and low temperatures, leading to frosty air from eastern directions. This is conducive to the formation of temperature inversion, which is usually maintained all the day and night, for several days.

The analysis of atmospheric pressure and presence of smog days and PM10 and PM2.5 concentrations recorded on both monitoring stations also allows us to conclude that the primary source of smog is the combustion of solid fuels in individual heating systems. This way of heating apartments is predominant in the center of Lodz, so it is not surprising that much higher concentrations of particulate matter and a bigger number of days with exceeded air quality standards are recorded at Station 2 (Gdańska Street) compared to Station 1 (Czernika Street) which is located outside the center in the area of new housing estates heated in the central system, i.e. by the CHP plant.

So we might risk a statement that one of the methods for fighting poor air quality in Poland, with frequent smog episodes in winter, should be the elimination of individual heating systems fueled with solid fuels and connecting residential areas in the city center to the heating system provided by CHP plants.

\section{References}

1. K. Ćwiek, G. Majewski, Przegląd Naukowy- Inżynieria i Kształtowanie Środowiska, 67, 54-66 (2015).

2. M. Sobolewski, Infos, 13, 217 (2016).

3. European Envoronmental Agency, Air quality in Europe - 2016 report

4. European Envoronmental Agency, Air quality in Europe - 2017 report

5. http://www.nytimes.com/interactive/2013/10/15/business/international/europe-airquality.html

6. http://wiadomosci.gazeta.pl/wiadomosci/7,114883,20072482,33-z-50-miast-ue-znajgorszym-powietrzem-jest-w-polsce-na-pierwszym.html

7. H. Shi, Y. Wang, J. Chen, D. Huisingh, J. Clean. Prod., 112, 1261-1271 (2016).

8. H.S. Kim, J.B. Huh, P.K. Hopke, T.M. Holsen, S.M. Yi, Atmos. Environ., 41, 67626770 (2007).

9. J. Cembrzyńska, E. Krakowiak, P.Z. Brewczyński, Medycyna Środowiskowa, 4, 31-38 (2012).

10. A. Fortelli, N. Scafetta, A. Mazzarella, Atmos. Environ., 143, 218-228 (2016).

11. S. Saberian, A. Heyes, N. Rivers, Resour. Energy. Econ., 49, 165-185 (2017).

12. M. Zhou, G. He, M. Fan, Z. Wang, Y. Liu, J. Ma, Z. Ma, J. Liu, Y. Liu, L. Wang, Y. Liu, Environ. Res., 136, 396-404 (2015).

13. J. Wang, K.W. Hipel, Y. Dang, Expert Syst. Appl., 87, 240-251 (2017).

14. H.E. Wichmann, Int. J. Hyg. Envir. Heal., 206, 505-520 (2004). 
15. Y.D. Wang, X.K. Fu, W. Jiang, T. Wang, M.H. Tsou, X.Y. Ye, Comput. Environ. Urban., 66, 110-116 (2017).

16. R. Cichowicz, G. Wielgosiński, W. Fetter, Environ. Monit. Assess., 189:605 (2017).

17. W. Meanhault, R. Vermeylen, M. Claeys, J. Vercauteren, E. Roekens, Sci. Total Environ., 562, 550-560 (2016).

18. M. M. T. de Rooji, D.J.J. Heederik, F. Borlée, G. Hoek, I.M. Wouters, Environ. Res., 153, 161-170 (2017).

19. D. Mira-Salama, C. Grüning, N. R. Jensen, P. Cavalli, J.P. Putaud, B.R. Larsen, F. Raes, H. Coe, Atmos. Res., 88, 294-304 (2008).

20. R. Cichowicz, G. Wielgosiński, A. Targaszewska, Ecol. Chem. Eng. S. 23, 1, 49-60 (2016).

21. K. Juda-Rezler, P. Manczarski, Nauka, 4, 97-106 (2010).

22. R. Cichowicz, G. Wielgosiński, Ecol. Chem. Eng. S., 22, 2, 189-200 (2015).

23. R. Cichowicz, G. Wielgosiński, Ecol. Chem. Eng. S., 22, 4, 513-525 (2015).

24. P. Michalik, Ochrona Srodowiska i Zasobów Naturalnych, 40 (2009).

25. Z. Yang, J. Wang, Environ. Res., 158, 105-117 (2017).

26. L. Megido, B. Suárea-Peña, L. Negral, L. Castrillón, S. Suáarez, Y. Fernándes-Nava, E. Marañón, Chemosphere, 162, 73-79 (2016).

27. J. Chen, H. Chen, Z. Wu, D. Hu, J.Z. Pan, Inform. Syst. J., 64, 281-297 (2017).

28. T.Y. Wong, J. Food Drug Anal., 25, 235-244 (2017).

29. S. Mishra, Indian Heart Journal, 69, 425-429 (2017).

30. A. Watkins, M. Danielewitz, M. Kusha, S. Massé, B. Urch, K. Quadros, D. Spears, T. Farid, K. Nanthakumar, Can. J, Cardiol., 29, 734-741 (2013).

31. C. Muiwijk, P.J.C. Schrijvers, S. Wuerz, S. Kenjereš, Atmos. Environ., 147, 470-484 (2016).

32. X. Wang, J. Chen, T. Cheng, R. Zhang, X. Wang, J. Environ. Sci., 26, 1894-1908 (2014).

33. B. Toczko, Biuletyn kwartalny Rządowego Centrum Bezpieczeństwa, 18, 18-21 (2017).

34. K. Kożuchowski, Klimat Polski - nowe spojrzenie, PWN, Warszawa 2011

35. http://geoportal.pgi.gov.pl/atlasy_gi/lodz

36. http://geoportal.pgi.gov.pl/atlasy_gi/lodz/mapy

37. http://www.wios.lodz.pl/Stacje_pomiarowe, 211 